\title{
Pengaruh Insentif dan Disiplin Kerja terhadap Produktivitas Kerja Karyawan pada PT. Infomedia Nusantara
}

\author{
Abdi Sugiarto \\ Universitas Tjut Nyak Dhien \\ mimoabdi2@gmail.com \\ Iqbal Ramadhan \\ Universitas Tjut Nyak Dhien \\ iramadhan391@gmail.com
}

\begin{abstract}
The purpose of this research is to find out what are the incentives and work discipline on the work productivity of employees at PT Infomedia Nusantara. This type of research is associative with the entire population of Infomedia call center services that open 156 employees, and the number of samples uses a Slovin sample which opens 88 employees. The form of the instrument used was a questionnaire with a Likert scale, the incentive questionnaire consisted of 7 statements, 9 questionnaire work disciplines and the questionnaire product consisted of 7 statements, all of the questionnaires were tested for validity and reliability. From the results of the questionnaire distribution for the incentive variable $\left(X_{1}\right), 58.4 \%$ agree, and $38.6 \%$ strongly agree, for the work discipline variable $\left(X_{2}\right), 60.2 \%$ agree, and 28.4 strongly agree, and for the productivity variable. obtained $68.8 \%$ agree and $28.6 \%$ strongly agree. From these data, it has fulfilled the classical assumption tests such as normality test, heteroscedasticity test, and multicollinearity test, and continued with hypothesis testing, t-test to determine partial effect and F-test to determine simultaneous effect. The conclusion obtained from the hypothesis test is that there is a partial or simultaneous influence of incentives and work discipline on the productivity of PT. Infomedia Nusantara. The influence of incentives and work discipline on productivity is $56.8 \%$.
\end{abstract}

Kata Kunci Insentif, Disiplin Kerja dan Produktivitas

\section{PENDAHULUAN}

Karyawan mempunyai peranan langsung dalam mengerjakan aktivitas perusahaan (Ente, 2013), hal ini mengakibatkan karyawan menjadi titik tolak keberhasilan dari sebuah organisasi, atau perusahaan seperti PT Infomedia Nusantara yang melayani jasa dibidang contact center. PT Infomedia Nusantara memiliki 156 operator call center, dan kendala yang sedang dihadapi PT Infomedia Nusantara adalah rendahnya produktivitas. Rendahnya produktivitas karyawan dapat dilihat dari semangat kerja, keterampilan, komunikasi dan banyak faktor lagi. Rendahnya produktivitas merupakan masalah yang harus segera diselesaikan karena produktivitas merupakan faktor penting bagi perusahaan untuk mencapai tujuan perusahaan tersebut (Rismayadi, 2015). Anoraga (2005) menyatakan ada sepuluh faktor yang mempengaruhi produktivitas karyawan diantaranya; (1) pekerjaan yang menarik; (2) upah; (3) keamanan dan perlindungan; (4) etos kerja; (5) lingkungan atau sarana; (6) promosi dan perkembangan diri sesuai dengan perusahaan; (7) terlibat dalam organisasi; (8) pengertian dan simpati persoalan pribadi; (9) kesetiaan pimpinan; dan (10) disiplin kerja. Salah satu penyebab produktivitas karyawan PT Infomedia Nusantara Medan rendah adalah pemberian insentif (Ekhsan \& Mariyono, 2020; Evi, 2009; Marpaung, 2014; Pranoto et al., 
2016; Rachman, 2013). Pemberian insentif diharapkan dapat memotivasi karyawan agar bekerja semaksimal mungkin, pengelolaan SDM merupakan kegiatan yang harus di lakukan oleh setiap perusahaan untuk menghasilkan SDM yang berkualitas. Pemberian insentif di PT Infomedia Nusantara masih kurang maksimal diberikan oleh perusahaan sehingga menurunkan produktivitas karyawan, karyawan merasa sudah memberikan lebih namun insentif yang diterima belum sesuai.

Selanjutnya disiplin kerja yang merupakan salah satu syarat untuk membantu karyawan meningkatkan produktivitasnya (Assagaf \& Dotulong, 2015; Hidayat \& Taufik, 2012; Labudo, 2013; Sunarsi, 2018), tanpa disiplin kerja yang baik, perusahaan akan mengalami kesulitan untuk mencapai tujuannya (Ernawati \& Rochmah, 2018; Fathona \& Tarigan, 2017). Seseorang akan melaksanakan tugasnya dengan baik dan penuh rasa tanggung jawab bila karyawan tersebut memiliki disiplin kerja yang tinggi (Syafrina, 2017; Yoesana, 2013). Untuk membangun sikap disiplin kerja yang tinggi, perlu adanya peraturan dan hukuman, perhargaan dan konsistensi (Hurlock, 1978), sehingga mendorong para karyawan agar mengikuti standar dan aturan yang berlaku. Disiplin kerja karyawan PT Infomedia Nusantara masih belum memenuhi standar perusahaan seperti istirahatnya yang melebihi waktunya, menitip login dan logout. Padahal perusahaan sendiri sudah menetapkan hukuman hukuman, bagi karyawan yang melanggar aturan perusahaan.

\section{LANDASAN TEORI}

\section{A. Produktivitas Kerja}

Produktivitas kerja adalah perbandingan antara output dengan input, dimana output-nya harus mempunyai nilai tambah dan teknik pengerjaannya yang lebih baik (Hasibuan, 2002). Banyak faktor yang mempengaruhi produktivitas kerja, baik yang berhubungan tenaga kerja maupun yang berhubungan dengan lingkungan perusahaan untuk meningkatkan produktivitas kerja (Anoraga, 2005). Sedangkan menurut (Syafrina, 2017) menyebutkan beberapa faktor yang dapat mempengaruhi produktivitas kerja adalah sebagai berikut; (1) tenaga kerja; (2) seni serta ilmu manajemen; (3) modal.

Menurut Simamora (2004) indikator yang digunakan dalam pengukuran produktivitas kerja meliputi kuantitas kerja, kualitas kerja dan ketepatan waktu. Sedangkan Sutrisno (2009) menyatakan untuk mengukur produktivitas kerja, menggunakan beberapa indicator diantanya; (1) kemampuan dalam melaksanakan tugas; (2) meningkatkan hasil yang dicapai; (3) semangat kerja; dan (4) mutu.

\section{B. Insentif}

Menurut Simamora (2004) mengatakan bahwa kompensasi Insentif (incentive compansasion) merupakan program kompensasi yang mengaitkan bayaran (pay) dengan produktivitas. Program Insentif berupaya untuk menghubungkan bayaran dengan kinerja guna mengimbali kinerja di atas rata-rata secara cepat dan langsung, juga untuk memperkuat hubungan kinerja-imbalan, dengan demikian, memotivasi kalangan karyawan yang terpengaruh. Program Insentif membayar seorang individu atau kelompok atas apa yang secara persis dihasilkannya. Sedangkan Hasibuan (2013) menyatakan insentif adalah tambahan balas jasa yang diberikan kepada pegawai tertentu yang prestasinya diatas prestasi standar. Upah insentif ini merupakan alat yang dipergunakan pendukung prinsip adil dalam pemberian kompensasi. Insentif dan bagi hasil (gainsharing) dapat digunakan sebagai alat untuk memotivasi para pegawai guna mewujudkan tujuan organisasi, karena keduanya merupakan pendekatan kompensasi yang memberi imbalan atas hasil kerja tertentu (Marwansyah, 2012). 
Pemberian insentif merupakan salah satu cara atau usaha perusahaan untuk meningkatkan kualitas kerja karyawannya (Kadarisman, 2012). Pemberian insentif oleh perusahaan merupakan upaya untuk memenuhi kebutuhan karyawannya. Insentif juga dapat dikatakan sebagai sarana motivasi yang mendorong para pegawai untuk bekerja dengan kemampuan optimal, yang dimaksudkan pendapatan ekstra di luar gaji atau upah yang telah ditentukan. Menurut ada beberapa prinsip perlunya diadakan upah insentif secara efektif, antara lain; (1) mengaitkan kinerja dengan program organisasi; (2) memenuhi standar kinerja karyawan; (3) memenuhi kebutuhan untuk mencapai tujuan organisasi; (4) nilai lebih untuk karyawan yang berprestasi; (5) sistem pembayaran yang adil; (6) rencana perusahaan (Dessler, 1997).

Beberapa faktor yang mempengaruhi insentif adalah jabatan, prestasi kerja, dan laba perusahaan (Suwatno \& Priansa, 2011). Pemberian insentif juga memiliki keunggulan dan kelemahannya. Keunggulannya pemberian insentif diantaranya; (1) meningkatkan produktivitas, meningkatkan pendapatan, memangkas biaya produksi; (2) memerlukan pengawasan (supervise) langsung pada tingkat luaran tertentu; (3) mendorong karyawan untuk menggunakan waktu dan sarana yang lebih efektif; (4) karyawan mendapatkan penentuan biaya tenaga kerja yang lebih akurat. Sedangkan kelemahan pemberian isentif adalah; (1) kualitas produk lebih buruk; (2) meningkatnya resiko kecelakaan kerja; (3) perlaksanaan sistem memerlukan biaya tambahan; (4) sukses semu yang terlalu mudah (Simamora, 2004). Insentif sendiri terbagai menjadi dua yakni insentif material yakni isentif dalam bentuk uang dan insentif non material yakni isentif tidak dalam bentuk uang, seperti hadiah, fasilitas liburan, penghargaan dan lain sebagainya (Suwatno \& Priansa, 2011).

\section{Disiplin Kerja}

Displin berasal dari kata dispel yang artinya patuh, patuh baik kepada pemimpin maupun kepada aturan (Fathona \& Tarigan, 2017). Disiplin adalah sikap kejiwaan dari seseorang atau sekelompok orang yang senantiasa berkehendak untuk mengikuti/mematuhi segala aturan yang telah ditetapkan (Hasibuan, 2002; Helmi, 1996; Sinungan, 2008). Disiplin kerja yang baik dapat dilihat dari kesadaran karyawan menaati peraturan dengan penuh tanggung jawab (Syafrina, 2017). Adapun peraturan-peraturan yang berkaitan dengan disiplin kerja adalah; (a) kehadiran; (b) tanggung jawab; (c) sikap; dan (d) norma. Tanpa disiplin yang baik, sulit bagi organisasi mencapai hasil yang optimal dengan demikian kedisiplinan harus ditegakkan dalam suatu organisasi perusahaan.

Banyak faktor yang mempengaruhi tingkat disiplin karyawan dalam menjalankan tugas dan kewajibannya, dengan demikian pimpinan perusahaan harus mengetahui faktor apa saja yang dapat mempengaruhi tingkat disiplin karyawan. Faktor yang mempengaruhi disiplin kerja adalah factor kepribadian dan faktor lingkungan (Arifin, 2017; Helmi, 1996). Faktor lainmempengaruhi disiplin karyawan adalah (1) pemberian kompensasi; (2) keteladanan pemimpin; (3) aturan yang tegas; (4) ketegasan pemimpin; dan (5) pengawasan (Singodimedjo, 2002), selanjutnya hasil penelitian juga menunjukkan bahwa kepemimpinan, komunikasi dan budaya organisasi juga merupakan faktor yang mempengaruhi disiplin kerja (Sugiharjo, 2016).

Helmi (1996) menguraikan indikator disiplin kerja diantaranya; (1) bekerja tidak karena waktu; (2) menaati peraturan bukan karena takut; dan (3) komitmen dan loyalitas pada organisasi. Sedangkan Fathona (2017) menyatakan indikator disiplin kerja adalalh; (1) tujuan dan kemampuan; (2) Teladan Pemimpin; (3) Balas jasa; (4) keadilan; (5) pengawasan; (6) Sanksi; (7) ketegasan; dan (8) hubungan kemamusiaan. 


\section{METODOLOGI PENELITIAN}

Tempat penelitian dilakukan di PT. Infomedia Nusantara Medan yang beralamat di Jl. S Parman, No. 315 I-J, Gedung Cambridge, Medan, Sumatera Utara pada Maret s.d Agustus 2020. Populasi dalam penelitian ini adalah seluruh karyawan PT Infomedia Nusantara yang berjumlah 156 orang. Dari 156 karyawan ditentukan sampel sebanyak 88 karyawan dengan rumus Solvin (Nazenin \& Palupiningdyah, 2014; Sandi \& Nurhayati, 2020), penentuan 88 karyawan tersebut secara acak. teknik pengumpulan data primer dengan penelitian lapangan, observasi dan penyebaran Questioner (Sumbangsih \& Nelisa, 2013). Sebelum digunakan instrument diuji keabsahan instrumen dan kekonsistenan instrument dengan Uji Validitas dan reliabilitas (Sugiyono, 2014). Setelah memperoleh data, seblum uji hipotesis data harus melalui Uji Asumsi Klasik yang terdiri uji normalitas, uji heterokedastisitas, dan uji multikoliniearitas (Janie, 2012). Pada uji hipotesis menggunakan uji-t untuk mengetahui pengaruh parsialnya dan uji $\mathrm{F}$ untuk mengetahui pengaruh simultannya (Janie, 2012). Untuk mengetahui persentasi pengaruh insentif dan disiplin kerja menggunakan uji koefisien determinasi.

\section{HASIL PENELITIAN}

Penulis telah menyebarkan sebanyak 88 kuisoner untuk karyawan yang menjadi sampel penilitian, untuk melihat apakah ada pengaruh antara insetif dan disiplin kerja terhadap produktivitas kerja karyawan pada PT Infomedia Nusantara, identitas responden yang ditanyakan adalah Jenis kelamin, Usia, Pendidikan terakhir dan lama kerja, hasil penelitian akan dibahas dibawah ini.

\section{Tabel 1. Karakteristik responden}

\begin{tabular}{|l|l|l|l|}
\hline Identitas Responden & Kriteria & Frekuensi & Persentase (\%) \\
\hline \multirow{4}{*}{ Usia } & $<25$ & 32 & 36,4 \\
\cline { 2 - 4 } & $26-30$ & 33 & 37,5 \\
\cline { 2 - 4 } & $>30$ & 23 & 26,1 \\
\hline \multirow{3}{*}{ Jenis Kelamin } & Laki-Laki & 41 & 46,6 \\
\cline { 2 - 4 } & Perempuan & 47 & 53,4 \\
\hline \multirow{2}{*}{ Jenjang Pendidikan } & $\mathrm{D} 3$ & 46 & 52,3 \\
\cline { 2 - 4 } & $\mathrm{S} 1$ & 42 & 47,7 \\
\hline \multirow{3}{*}{ Lama Kerja } & $<2$ tahun & 36 & 40,9 \\
\cline { 2 - 4 } & $3-6$ tahun & 44 & 50,0 \\
\cline { 2 - 4 } & $>6$ tahun & 8 & 9,1 \\
\hline
\end{tabular}

Sebelum data diolah lebih lanjut, untuk setiap instrument angket yang disebar harus melalui uji kelayakanya, apakah bisa diteruskan untuk penelitian selanjutnya atau tidak, dalam penelitian ini uji kelayakan angket yang digunakan adalah uji validitas dan reliabilitas. Ujia validitas yang digunakan adalah korelasi product moment. Hasil uji validitas yang diperoleh semua item penyataan setiap variabel dinyatakan valid dengan taraf signifikan 0,05 , dan $\mathrm{r}$ tabel senilai 0.207. sedangkan Uji Reliabilitas merupakan tingkat keandalan suatu instrumen penelitian, sehingga instrumen dapat digunakan berulang kali untuk mengukur objek yang sama akan menghasilkan data yang sama. Untuk mengetahui kestabilan dan konsisten responden dalam menjawab butir-butir berkaitan dengan konstruk pertanyaan yang disusun dalam bentuk kuesioner. Uji reliabel menggunakan Cronbach alpha dengan $\alpha>0.6$, berdasarkan hasil analisis diperoleh $\alpha=0,875$ untuk variabel insentif $\left(\mathrm{X}_{1}\right) ; \alpha=0,612$ untuk variabel disiplin kerja $\left(\mathrm{X}_{2}\right)$; dan $\alpha=0,871$ untuk variabel produktivitas kerja (Y). 
Dibawah ini akan dijelaskan persentase jawaban responden untuk setiap pernyataan yang sudah disebar kepada respoden dimana dalam penelitian ini terdapat 7 pernyataan untuk variabel insentif $\left(X_{1}\right), 9$ pernyataan untuk variabel disiplin kerja $\left(X_{2}\right)$ dan 7 pernyataan untuk variabel produktivitas $(\mathrm{Y})$.

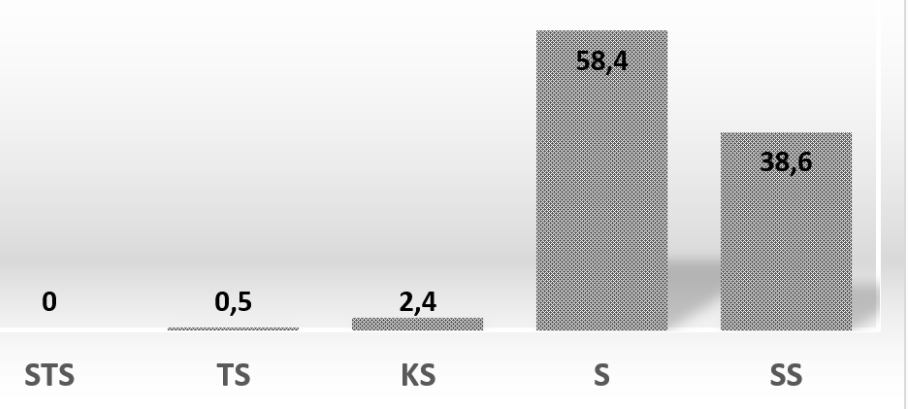

Gambar 1. Persentase jawaban responden variabel $\mathrm{X}_{1}$ (Insentif)

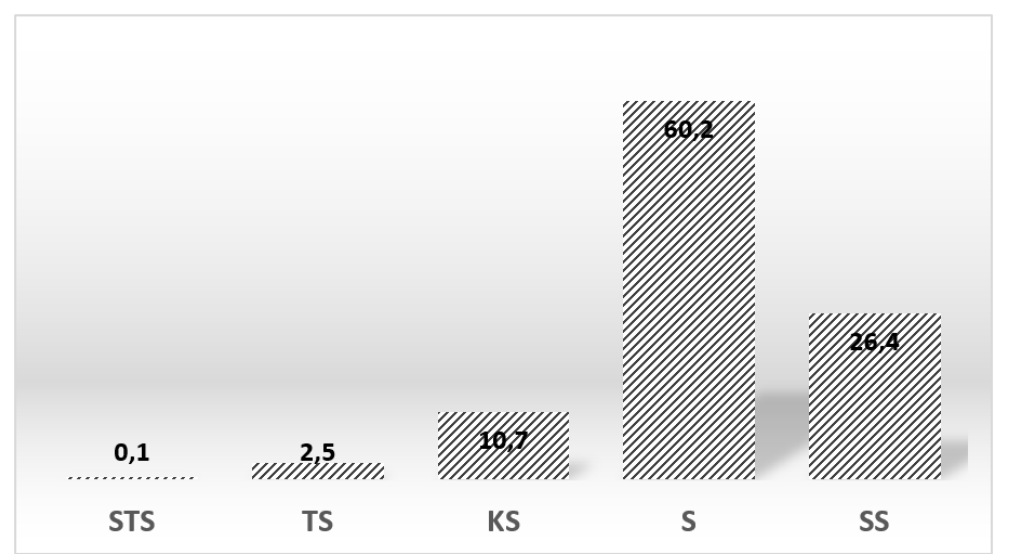

Gambar 2. Persentase jawaban responden variabel $\mathrm{X}_{2}$ (Disiplin Kerja)

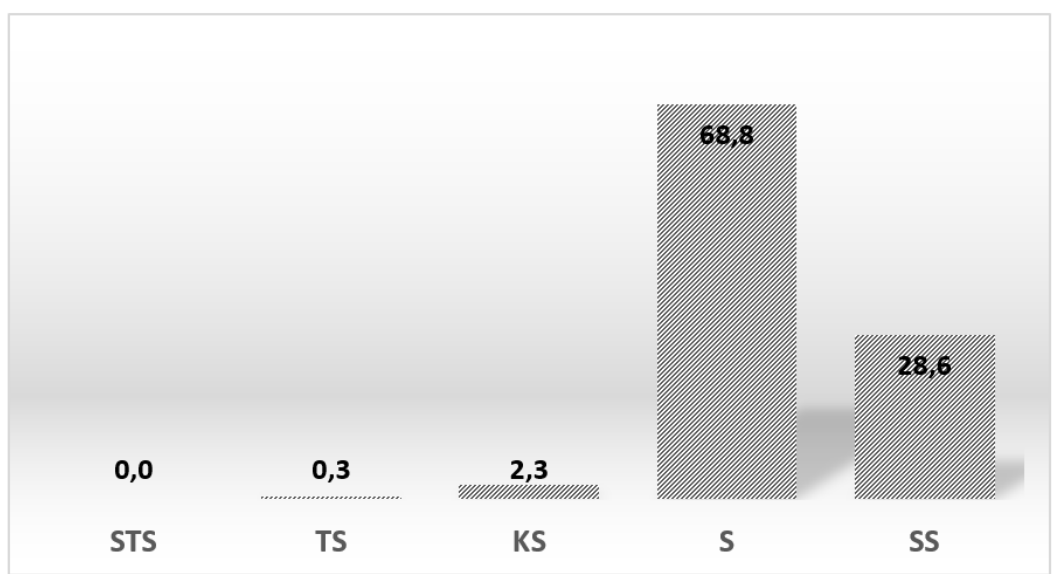

Gambar 3. Persentase jawaban responden variabel Y (Produktivitas)

Pengujian asumsi klasik dilakukan untuk memenuhi syarat analisis regresi berganda untuk menghasilkan model regresi berganda yang signifikan dan akurat. Beberapa uji asumsi klasik yang dilakukan adalah uji normalitas, uji heterokedastisitas, dan uji multikolinieritas. 
Uji Normalitas bertujuan untuk mengetahui apakah distribusi sebuah data mengikuti atau mendekati distribusi normal. Uji normalitas dilakukan dengan menggunakan pendekatan kurva PP-Plots, kurva tersebut dapat dilihat pada gambar di bawah ini.

\section{Dependent Variable: Produktivitas}

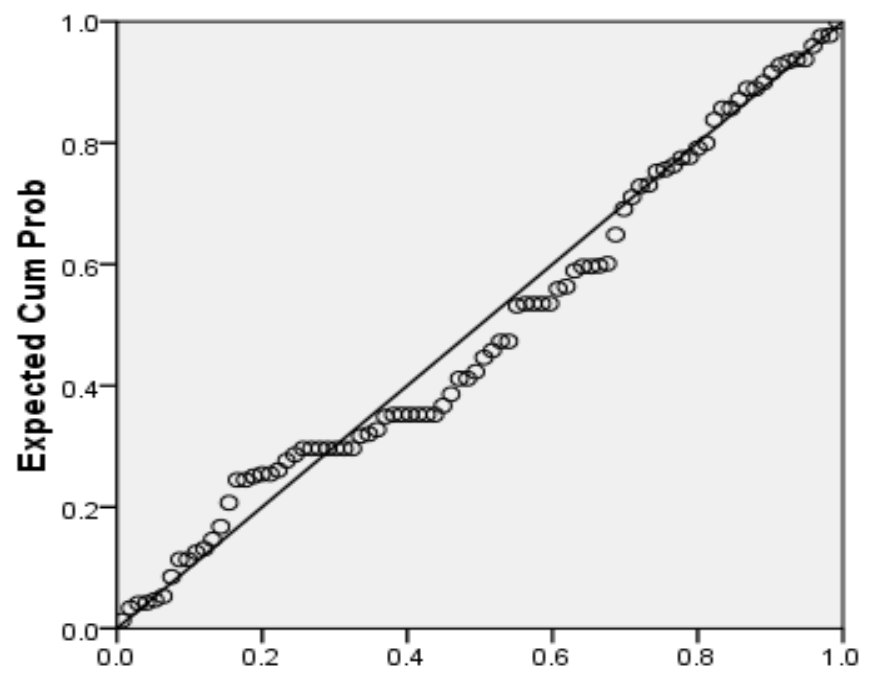

Gambar 4. P-plot Normalitas

Berdasarkan gambar diatas mengindikasikan bahwa sebaran data cenderung mengikuti garis linier, sehingga dapat disimpulkan data penelitian berdistribusi normal. Selanjutnya uji heteroskedastisitas bertujuan untuk menguji apakah sebuah grup mempunyai varians yang sama di antara anggota grup tersebut. Dengan kata lain, jika varians variabel independent adalah konstan (sama) untuk setiap nilai tertentu variabel independen disebut homoskedastisitas. Untuk menentukan heterokdedastisitas menggunakan hasil representasi Scatterplot, dan hasilnya dapat dilihat pada gambar di bawah ini. Untuk melihat keheterokedastisitasnya dengan menganalisis hasil scatterplot, jika gambar menunjukkan penyebaran data, maka data heterokedastisitas dan sebaliknya.

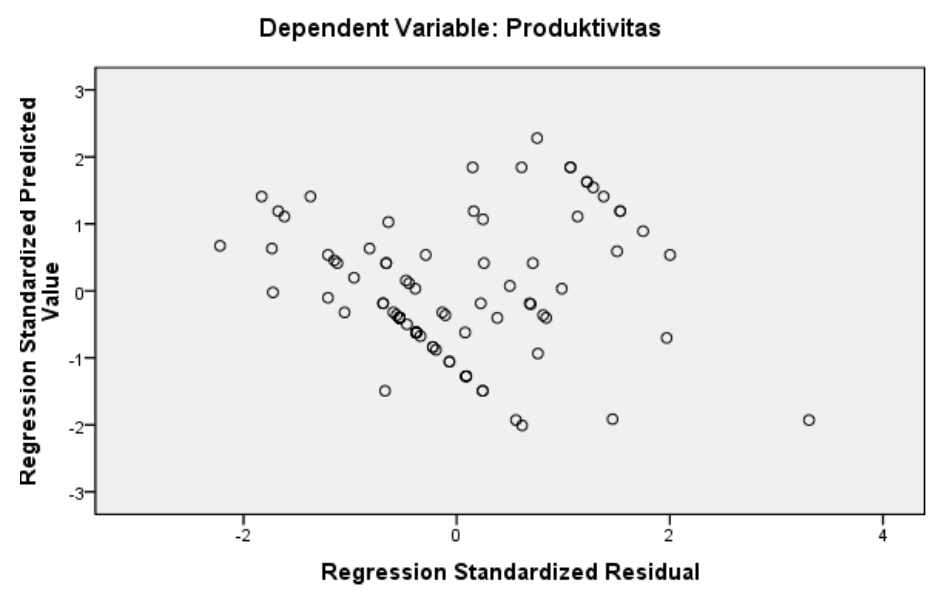

Gambar 5. Hasil Output Scatterplot

Berdasarkan hasil scatterplot di atas maka dapat disimpulkan data memenuhi syarat heterokedastisitas. Uji asumsi klasik selanjutnya adalah uji multikoliniearitas, uji ini untuk melihat apakah pada model regressi ditemukan kolerasi yang kuat antar variable independent, untuk menentukan uji multikolinieritas dengan melihat nilai tolerance dan VIF. Berdasarkan 
tabel di bawah kedua variabel independen memiliki nilai tolerance 0,955 dimana nilai tersebut dalam batas tolenransi yakni lebih besar 0,1 , sehingga dapat disimpulkan tidak terjadi multikolinearitas dalam varaibel independent penelitian.

Tabel 2. Coefficients ${ }^{\mathrm{a}}$

Uji Multikoliniearitas

\begin{tabular}{|c|c|c|c|c|c|}
\hline \multirow[b]{2}{*}{ Model } & \multicolumn{2}{|c|}{ Unstandardized Coefficients } & \multirow{2}{*}{\begin{tabular}{|c|} 
Standardized Coefficients \\
Beta \\
\end{tabular}} & \multicolumn{2}{|c|}{ Collinearity Statistics } \\
\hline & $B$ & Std. Error & & Tolerance & VIF \\
\hline 1 (Constant) & 4.948 & 4.074 & & & \\
\hline Insentif & .404 & .081 & .44 & .9 & 1.047 \\
\hline Disiplin kerja & .340 & .103 & .29 & .9 & 1.047 \\
\hline
\end{tabular}

a. Dependent Variable: Produktivitas

Untuk menguji pengaruh insentif $\left(\mathrm{X}_{1}\right)$, disiplin kerja $\left(\mathrm{X}_{2}\right)$ terhadap Produktivitas $(\mathrm{Y})$ menggunakan multiple regression analysis model. Dengan berbantuan SPSS diperoleh table koefisien persamaan regresi berganda di bawah ini.

Tabel 3. Coefficients ${ }^{\mathrm{a}}$ Uji Regressi Berganda

\begin{tabular}{|l|r|r|r|r|r|}
\hline \multirow{2}{*}{ Model } & \multicolumn{2}{|l|}{ Unstandardized Coefficients } & Standardized Coefficients & & \\
\cline { 2 - 5 } & \multicolumn{1}{|c|}{$\mathrm{B}$} & Std. Error & Beta & \multicolumn{1}{c|}{ S } & Sig. \\
\hline 1 (Constant) & 4.948 & 4.074 & & 1.214 & .228 \\
Insentif & .404 & .081 & .446 & 4.957 & .000 \\
Disiplin kerja & .340 & .103 & .298 & 3.310 & .001 \\
\hline
\end{tabular}

a. Dependent Variable: Produktivitas

Berdasarkan tabel di atas maka persamaan regresi berganda yang mengaitkan antar variabel adalah $\widehat{Y}=4.948+0,404 X_{1}+0,340 X_{2}+$ e. Dari persamaan regresi yang diperoleh dapat diartikan bahwa setiap naik 1 satuan variabel insentif maka variabel produktivitas akan meningkat sebesar 0,404, selanjutnya jika naik 1 satuan variabel disiplin kerja maka variabel produktivitas akan meningkat sebesar 0,340 satuan. Kemudian langkah terakhir adalah pengujian hipotesis, pengujian hipotesis dilakukan secara parsial dengan uji-T dan secara simultan dengan uji-F. Kriteria pengambilan keputusan uji-T adalah apabila $t_{\text {hitung }}>t_{\text {tabel }}$ dan tingkat signifikansi $(\alpha)<0,05$ maka Ha ditolak (H0 diterima), dan sebaliknya. Hasil uji-T yang dilakukan diperoleh tabel 3 di atas.

Dari tabel diatas diperoleh nilai thitung untuk variabel insentif 4,957 sehingga $t_{\text {hitung }}>t_{\text {tabel }}$ $(4.957>1,987)$ artinya terdapat pengaruh antara insentif terhadap produktivitas, demikian juga untuk taraf signifikan $0,000<0,05$ sehingga $\mathrm{H}_{0}$ ditolak sehingga dapat disimpulkan bahwa insentif berpengaruh dan signifikan terhadap produktivitas karyawan PT Infomedia Nusantara. selanjutnya disiplin kerja nilait thitung 3.310 sehingga thitung $(3,310)>t_{\text {tabel }}(1,987)$ dan taraf sig. 0,001 $<0,05$ artinya terdapat pengaruh antara disiplin kerja terhadap produktivitas, dengan demikian $\mathrm{H}_{0}$ ditolak dan dapat disimpulkan bahwa disiplin kerja berpengaruh dan signifikan terhadap produktivitas karyawan PT Infomedia Nusantara. Uji-F atau uji simultan untuk melihat pengaruh variabel-variabel independen terhadap variabel dependen secara bersama-sama (simultan). Kriteria pengujian hipotesisnya jika $F_{\text {hitung }}<F_{\text {tabel }}$ maka insentif dan disiplin kerja secara bersama sama tidak berpengaruh terhadap produktivitas karyawan pada PT Infomedia Nusantara, dan sebaliknya. Uji F menggunakan uji Anova dua jalur dan diperoleh tabel di awabah ini. 


Tabel 4. ANOVA
\begin{tabular}{|l|r|r|r|c|c|}
\hline Model & Sum of Squares & Df & Mean Square & F & Sig. \\
\hline 1 Regression & 211.724 & 2 & 105.862 & 22.240 & $.000^{a}$ \\
Residual & 404.594 & 85 & 4.760 & & \\
Total & 616.318 & 87 & & & \\
\hline
\end{tabular}
a. Predictors: (Constant), Disiplin kerja, Insentif
b. Dependent Variable: Produktivitas

Dari tabel diatas terlihat nilai untuk $F_{\text {hitung }} 22.240$ dan Sig. 0,000, dengan taraf signifikan $5 \%(0,05)$ dan $\mathrm{dk}=86)$ diperoleh nilai $\mathrm{F}_{\text {tabel }}=3,10$. Jika dibandingkan dengan $\mathrm{F}_{\text {tabel }}$ dan $\mathrm{F}_{\text {hitung }}$ maka $F_{\text {hitung }}(22,240)>F_{\text {tabel }}(3.10)$, sehingga $\mathrm{H}_{\mathrm{o}}$ ditolak dan dapat diartikan bahwa insentif dan disiplin kerja secara bersama-sama berpengaruh terhadap produktivitas karyawan PT Infomedia Nusantara Medan. Untuk mengetahui besar dampak variabel bebas terhadap variabel terikat diperlukan analisis koefisien determinasi, berdasarkan tabel di bawah ini diperoleh nilai $\mathrm{R}$ sebesar 0,586, nilai tersebut menunjukkan pengaruh disiplin kerja dan isentif sebesar 58,6\% terhadap produktivitas karyawan PT Infomedia Nusantara Medan dan sisanya $41,4 \%$ dipengaruhi oleh faktor lain.

Tabel 5. Model Summary

\begin{tabular}{|l|r|r|r|r|}
\hline Model & \multicolumn{1}{|c|}{$\mathrm{R}$} & R Square & Adjusted R Square & $\begin{array}{c}\text { Std. Error of the } \\
\text { Estimate }\end{array}$ \\
\hline 1 & $.586^{\mathrm{a}}$ & .344 & .328 & 2.18173 \\
\hline
\end{tabular}

a. Predictors: (Constant), Disiplin kerja, Insentif

Dengan adanya insentif, karyawan perusahaan diharapkan dapat meningkatkan produktivitas kerja, kualitas kerja, pemikiran yang beriorentasi memajukan instansi, menurunkan tingkat absensi maupun perputaran tenaga kerja, sehingga hal tersebut dapat mendorong karyawan bekerja lebih giat, semangat dan rasa penuh tanggung jawab terhadap pekerjaannya yang bisa berefek juga menurunkan angka korupsi dikalangan karyawan tersebut, Hasil penelitian menunjukkan bahwa terdapat hubungan positif antara insentif dengan produktivitas karyawan PT Infomedia Nusantara. Pada dasarnya tujuan pokok dari semua program insentif adalah meningkatkan produktivitas para karyawan guna mencapai suatu keunggulan kompetitif (Kadarisman, 2012). Hasil penelitian ini sejalan dengan hasil penelitian Marpaung (2014) yang menyimpulkan bahwa insentif berpengaruh terhadap produktivitas, Insentif yang sesuai akan menaikkan produktivitas dikarena meningkatkan kepuasan kerja. Tujuan utama disiplin adalah untuk meningkatkan efisiensi semaksimal mungkin dengan cara mencegah pemborosan waktu dan energy. Hasil penelitian menunjukkan bahwa terdapat pengaruh antara disiplin kerja terhadap produktivitas karyawan PT Infomedia Nusantara. Hasil penelitian ini juga didukung oleh hasil penelitian yang dilakukan oleh Christian \& Farida (2016). Pengaruh insentif dan disiplin kerja terhadap produktivitas karyawan secara signifikan sebagaimana yang diperoleh dari hasil penelitian ini didukung dari hasil penelitian-penelitian lain seperti Kurniawan, (2017).

\section{KESIMPULAN}

Adapun kesimpulan yang bisa diambil dari penelitian ini adalah terdapat pengaruh yang signifikan pemberian insentif terhadap produktivitas karyawan PT. Infomedia Nusantara Medan. Kesimpulan lain juga terdapat pengaruh yang signifikan disiplin kerja terhadap 
produktivitas karyawan PT. Infomedia Nusantara Medan. Pemberian insentif dan disiplin kerja secara bersama-sama mempengaruhi produktivitas karyawan PT. Infomedia Nusantara Medan sebesar 58,6\%.

\section{DAFTAR PUSTAKA}

Anoraga, P. (2005). Manajemen Bisnis. Rineka Cipta.

Arifin, M. (2017). Strategi Manajemen perubahan dalam meningkatkan disiplin diperguruan tinggi. EDUTECH Ilmu Pendidikan Dan Ilmu Sosial, 3 No 1(1), 117-132.

Assagaf, S. C. Y., \& Dotulong, L. O. H. (2015). Pengaruh Disiplin, Motivasi Dan Semangat Kerja Terhadap Produktivitas Kerja Pegawai Dinas Pendapatan Daerah Kota Manado. Jurnal Riset Ekonomi, Manajemen, Bisnis Dan Akuntansi, 3(2), 639-649. https://doi.org/10.35794/emba.v3i2.8692

Christian, F. A., \& Farida, L. (2016). Pengaruh Disiplin Kerja Terhadap Produktivitas Kerja Karyawan Bagian Produksi Pabrik Kelapa Sawit (PKS) PT. Perkebunan Nusantara V Sei Rokan KEC. JOM Fisip, 3(1).

Dessler, G. (1997). Manajemen Sumber Daya Manusia, Edisi Bahasa Indonesia (2nd ed.). Prenhalindo.

Ekhsan, M., \& Mariyono, R. (2020). Pengaruh Gaya Kepemimpinan Islami, Budaya Organisasi Islami dan Insentif terhadap Produktivitas Kerja Karyawan PT Yanmar Indonesia. Jesya (Jurnal Ekonomi \& Ekonomi Syariah), 3(2), 265-275. https://doi.org/10.36778/jesya.v3i2.188

Ente, M. T. H. (2013). Peran Karyawan Perusahaan daerah Pasar terhadap Pendapatan Asli Daerah (PAD) Kota Manado (Suatu Studi di Pasar Tumiting). Encephale, 53(1), 5965. http://dx.doi.org/10.1016/j.encep.2012.03.001

Ernawati, F. Y., \& Rochmah, S. (2018). Membangun Kinerja Karyawan Melalui Kompensasi, Kompetensi dan Disiplin Kerja terhadap Kinerja Perawat RSI Sultan Agung Semarang. Jurnal Fokus Ekonomi, 13(2), 331-341.

Evi, T. (2009). Kajian Teoritis Analisa Hubungan Pemberian Insentif Dengan Semangat Kerja Karyawan. Seminar Nasional Informatika, 65-71. http://repository.upnyk.ac.id/39/1/E-9_evi-pardede-54.pdf

Fathona, N. E., \& Tarigan, C. Y. (2017). Pengaruh Kompetensi dan Disiplin Kerja terhadap Kinerja Karyawan di PT Dasar Rukun. Journal of Chemical Information and Modeling, 4(2), 27-49.

Hasibuan, M. (2002). Organisasi dan Motivasi Dasar Peningkatan Produktivitas. Bumi Aksara.

Hasibuan, M. (2013). Manajemen Sumber Daya Manusia Edisi Revisi (Revisi). Bumi Aksara.

Helmi, A. F. (1996). Berk:Ualitas. Buletin Psikologi, 4(2), 32-41.

Hidayat, Z., \& Taufik, M. (2012). Pengaruh Lingkungan Kerja Dan Disiplin Kerja Serta Motivasi Kerja Terhadap Kinerja Karyawan. Jurnal WIGA2, 2(1), 79-97. https://doi.org/10.33373/dms.v7i2.1702

Hurlock, E. B. (1978). Pekembangan Anak (M. M. Tiandrasa (ed.); 6th ed.). Erlangga.

Janie, D. N. A. (2012). Statistik Deskriptif \& Regresi Linier Berganda dengan SPSS. 
Semarang University Press.

Kadarisman, M. (2012). Manajemen Kompensasi. Rajawali Pers.

Kurniawan, S. (2017). Pengaruh Insentif Finansial Dan Disiplin Kerja Terhadap Produktivitas Kerja Karyawan Bagian Produksi CV. Lezatku Food Pringsewu Lampung, .

Labudo, Y. (2013). Disiplin Kerja Dan Kompensasi Pengaruhnya Terhadap Produktivitas Karyawan. Jurnal Riset Ekonomi, Manajemen, Bisnis Dan Akuntansi, 1(3), 55-62. https://doi.org/10.35794/emba.v1i3.1372

Marpaung, J. F. (2014). Pemberian Insentif Terhadap Peningkatan Produktivitas Kerja Karyawan Pada Pt . Inited Dico Citas. Manajemen Dan Informatika Komputer Pelita Nusantara, 15(1), 117-122.

Marwansyah. (2012). Manajemen Sumber Daya Manusia. Alfabeta.

Nazenin, S., \& Palupiningdyah, P. (2014). Peran Stres Kerja Dan Kepuasan Kerja Untuk Mengurangi Turnover Intention. Jurnal Dinamika Manajemen, 5(2), 220-227. https://doi.org/10.15294/jdm.v5i2.3663

Pranoto, E., Haryono, A. T., \& Warso, M. M. (2016). Pengaruh Rekrutmen, Stress Kerja dan Pemberian Insentif Terhadap Produktivitas Kerja dengan Komitmen Organisasi sebagai Variabel Intervening Pada PT. Ungaran Sari Garment Unit III Congol Karangjati.". Jurnal of Managemen, 2(2), 51-64.

Rachman, R. (2013). Pengaruh Insentif dan Senioritas terhadap Produktivitas Kerja Karyawan pada Modelux Center. Jurnal Economix, 1(2), 10-34.

Rismayadi, B. (2015). FAKTOR-FAKTOR YANG MEMPENGARUHI PRODUKTIVITAS KARYAWAN (Studi Kasus pada CV Mitra Bersama Lestari Tahun 2014). Jurnal Manajemen \& Bisnis Kreatif, 1(1), 1-16. https://doi.org/10.36805/manajemen.v1i1.53

Sandi, A., \& Nurhayati, M. (2020). Effect of Entrepreneurship Education, Family Environment and Self-Efficacy on Students Entrepreneurship Intention. 120(Icmeb 2019), 9-12. https://doi.org/10.2991/aebmr.k.200205.003

Simamora, H. (2004). Manajemen Sumber Daya Manusia. STIE YKPN.

Singodimedjo. (2002). Manajemen Sumber Daya Manusia. Bumi Aksara.

Sinungan, M. (2008). Produktivitas Apa dan Bagaimana. Bumi Aksara.

Sugiharjo, R. J. (2016). Faktor-faktor yang Mempengaruhi Disiplin Kerja Pegawai. Jurnal Ilmiah Manajemen Dan Bisnis, 2(1), 146-153.

Sugiyono. (2014). Metode Penelitian Pendidikan Pendekatan Kuantitatif, Kualitatif, dan $R \& D$. Alfabeta.

Sumbangsih, N., \& Nelisa, M. (2013). Pengaruh pemberian insentif terhadap motivasi kerja pustakawan di perpustakan Universitas Bung Hatta Padang. Jurnal Akuntansi Manajemen, 2(9), 178-185.

Sunarsi, D. (2018). Pengaruh Motivasi Dan Disiplin Terhadap Produktivitas Kerja Karyawan Pada Pt. Nadi Suwarna Bumi. JURNAL SeMaRaK, 1(1), 66-82. https://doi.org/10.32493/smk.v1i1.1247 
Sutrisno, E. (2009). Manajemen Sumber Daya Manusia (1st ed.). Kencana Prenada Media Group.

Suwatno, \& Priansa, D. (2011). Manajemen SDM dalam Organisasi Publik dan Bisnis. Alfabeta.

Syafrina, N. (2017). Pengaruh Disiplin Kerja Terhadap Kinerja Karyawan Pada PT. Suka Fajar Pekan Baru. Eko Dan Bisnis, 4(8), 1-12. https://ekobis.stieriauakbar.ac.id/index.php/Ekobis/article/view/5

Yoesana, U. (2013). Hubungan Antara Motivasi Kerja Dengan Disiplin Kerja Pegawai di Kantor Kecamatan Muara Jawa Kabupaten Kutai Kartanegara. EJournal Pemerintahan Integratif, 1(1), 13-27. 